\title{
AL-QUR'AN SEBAGAI SUMBER TEKSTUAL FILSAFAT ISLAM
}

\author{
Wardani \\ Jurusan Tafsir Hadis Fakultas Ushuluddin dan Humaniora \\ IAIN Antasari Banjarmasin
}

\begin{abstract}
This article is intended to argue against those who say that the Islamic philosophy is really nothing more than the true ancient Greek philosophy that has been "repacked" by Islam, and to prove that Islamic philosophy, while being as a result of historical process of its adopting of Greek philosophy, is to large extent the own Muslim thinkers' thoughts by "adapting" that philosophical tradition with Islamic doctrine. As the result, they have sought to compromise between rational and revealed truth. Therefore, it sees that Islamic philosophy is a attempt to interpret the Qur'an in the light of reason. By this way of argumentation, the author wishes to say that the balanced view of the origin of Islamic philosophy, e.g. between the historical and textual roots or between influence and originality, must be recognized, so that we will have a holistic understanding of the existence of this philosophical tradition in Islam.
\end{abstract}

Kata kunci: al-Qur'an, sumber tekstual, filsafat Islam, filsafat Yunani

\section{Pendahuluan}

Ada dua perspektif untuk melihat keberadaan filsafat Islam. Pertama, perspektif sejarah. Dengan perspektif ini, filsafat Islam dilihat sebagai mata rantai dari filsafat-filsafat atau pemikiranpemikiran yang ada sebelumnya. Bentuk ekstrem dari perspektif sejarah ini adalah kesimpulan yang menyatakan bahwa filsafat Islam hanya merupakan filsafat Yunani-Alexandria yang kemudian di kalangan filosof Islam dikemas dengan "baju" Islam. Kita sebenarnya tidak bisa menolak bahwa filsafat Islam tidak mungkin tumbuh tanpa adanya proses transmisi ilmu-ilmu di luarnya. Kedua, di samping akar sejarahnya tersebut, perkembangannya yang begitu mengesankan dalam sejarah intelektual juga diiringi dengan kreativitas dan orisinalitas Islam. Dalam konteks ini, setiap perkembangan ilmu Islam harus dirunut kepada kitab suci, karena kaum muslimin, sebagaimana umat yang lain, adalah umat yang mengikatkan diri secara kuat dengan kitab suci. Oleh karena itu, seperti cabang ilmu Islam lainnya, filsafat Islam bersumber dari al-Qur'an dan hadits di samping sumber historisnya.

Para filosof Islam sejak al-Kindî hingga al-'Allâmah ath-Thabâthabâ'î menarik pemikiranpemikirannya dari al-Qur'an dan hadits sebagai sumber sentralnya. Bahkan, mereka mengkritik pemikiran-pemikiran yang bertentangan dengan kedua sumber tersebut. Di samping bersikap rasional-netralis, mereka adalah penganut setia agama (fidest). Oleh karena itu, idak heran jika beberapa filosof Islam sekaligus merupakan ahli dalam hukum Islam (faqîh, jusrist) seperti Ibn Rusyd yang menulis Bidâyat al-Mujtabid (tentang fiqh perbandingan) dan al-Ghazâlî yang menulis al-Mustashfâ min Ilm al-Ushûl (tentang ushûl al-fiqh). Padahal Ibn Rusyd sendiri dengan alirannya, Averroism atau Rusydiyyah, diidentikkan di Barat dengan gerakan pemikiran anti-keimanan. 
Karena keterkaitan kuatnya dengan al-Qur'an dan hadits, Seyyed Hossein Nasr dan Henry Corbin menyebut filsafat Islam dengan "filsafat profetik" atau "filsafat kenabian" (prophetic philosophy), meskipun keterikatan sebagian filosof Islam dengan kedua sumber tersebut masih diperdebatkan, seperti Muhammad ibn Zakariyyâ’ ar-Râzî yang menolak pengetahuan dari kenabian. Tapi, bahwa kedua sumber tersebut mengkristal kuat dalam pemikiran-pemikiran filsafat Islam, apalagi filsafat Islam adalah sebuah upaya mengharmonisasikan kebenaran rasional spekulatif filsafat dengan kebenaran absolut wahyu, atau upaya memberikan dasar penjelasan rasional bagi ajaran Islam. ${ }^{1}$

\section{Filsafat Islam: Antara Pilihan Kebenaran Wahyu dan Kebenaran Akal}

Salah satu fakta terpenting tentang keterkaitan filosof Islam dengan sumber tekstual adalah pandangan tentang akal ('aq). Karena ketika seorang filosof beragama, dalam pencarian kebenaran ia dihadapkan dengan dua sumber, yaitu sumber kebenaran absolut yang diberikan oleh tuhan (revealed knowledge) berupa kitab suci dan kebenaran rasional sebagai hasil kreasinya dalam berpikir (acquired knowledge, pengetahuan hasil pencarian manusia). Dua kebenaran tersebut bertarung dalam kesadaran seorang filosof. Dalam aktivitas berpikir rasional, apa yang disebut sebagai pemikiran spekulatif mengambil dua macam bentuk. Pertama, pemikiran spekulatif murni, yaitu pemikiran bebas rasional manusia yang mendalam tanpa dibatasi oleh batas kebenaran lain, seperti pemkiran filsafat Yunani. Kedua, pemikiran spekulatif yang tidak murni seluruhnya bebas, yaitu spekulasi yang tidak mengasumsikan pemikiran yang bebas, tapi masih mempertimbangkan kebenaran kitab suci. Dalam kaitannya dengan pandangan filosof Islam tentang akal, rasionalitas bukanlah mengasumsikan kebebasan tak terbatas, seperti pemikiran spekulatif murni kalangan filosof Yunani, melainkan sebuah pemkiran rasional yang mencari kesesuaian antara pemikiran rasional manusia dengan kebenaran yang diberikan melalui kitab suci.

Sebagai contoh untuk menjelaskan posisi spekulasi filosof Islam untuk mencari kebenaran, kita kemukakan argumen sebab-akibat atau yang dikenal juga dengan argumen penyebaban (causation) untuk membuktikan secara rasional adanya tuhan. Argumen ini menjelaskan bahwa rangkaian sebab-akibat (A-B-C-D dst...), di mana A menjadi sebab dan B menjadi akibat dari A sekaligus sebagai sebab bagi C, dst. Seperti layaknya dalam kelahiran manusia. Pemikiran spekulatif tidak bisa menerima berdasarkan pertimbangan rasional bahwa rangkaian sebabakibat tersebut berlanjut tanpa akhir, karena jika A sebagai sebab dan kembali ke A, maka sebenarnya tidak ada sebab dan akibat. Untuk menjelaskan hal ini, para filosof memiliki konsep yang disebut dengan ad infinitum, yaitu ketidakmungkinan secara rasional rangkaian sebab-akibat tersebut berlanjut tanpa akhir. Dalam logika, prinsip ini mirip dengan istilah yang dikenal dengan petitio principii atau fallacy of begging question. ${ }^{2}$

${ }^{1}$ Seyyed Hossein Nasr, "The Qur'an and Hadith as Source and Inspiration of Islamic Philosophy”, dalam Seyyed Hossein Nasr dan Oliver Leaman (eds.), History of Islamic Philosophy (London dan New York: Routledge, 1996), Part 1, h. 28.

${ }^{2}$ Maksudnya adalah logika yang kesimpulannya ditarik dari premis-premis yang kebenarannya justeru masih perlu dibuktikan, padahal premis seharusnya jelas kebenarannya. Nalar keliru ini disebut juga "nalar berputar" (sirkular). Contoh analogi yang keliru seperti ini: Alam semesta memiliki permulaan (premis mayor). Setiap yang memiliki permulaan mesti ada subjek yang mengawali atau yang menciptakannya (premis minor). Jadi, alam semesta ini memiliki subjek yang 
Solusi atau jalan keluar dari mustahilnya ketakterhinggaan rangkaian sebab-akibat tersebut, akhirnya, dengan mengajukan konsep tentang adanya "penyebab utama" (bahasa Inggris: prime cause, Latin: prima causa). Konsep semula dikemukakan oleh Aristoteles dalam buku kedua Metaphysics. Filsafat Aristoteles ini diadopsi oleh kalangan filosof Islam untuk membuktikan adanya tuhan sebagai "penggerak utama" yang tidak bergerak lagi (unmoved mover, al-mubarrik al-awwal alladî́ lâ yataharrak). Argumen Aristoteles ini diterima oleh kalangan filosof Islam aliran Peripatetik (masysyâiyah), seperti Ibn Sînâ dan diterapkan juga oleh kalangan filosof skolastik Kristen, seperti St. Thomas Aquinas dan Summa contra Gentiles.

Belakangan, argumen spekulatif untuk membuktikan secara rasional tentang adanya tuhan tersebut dikritik oleh beberapa filosof modern, antara lain Emmanuel Kant dan Bertrand Russel. Kutipan berikut menunjukkan kritik Russel terhadap nalar spekulatif seperti itu:

That very simple sentence showed to me, as I still think, the fallacy in the argument of the First Cause. If everything must have a cause, than God must have a cause. If there can be anything without a cause, it may just as well be the world as God, so that there cannot be any validity in that argument. ${ }^{3}$

I find among many people at the present day an indifference to truth which I cannot but think extremely dangerous. When people argue, for example, in defence of Christianity, they do not, like Thomas Aquinas, give reasons for supposing that there is a God ang He has expressed His will in the scripture. ${ }^{4}$

Kalimat yang sangat sederhana tersebut memperlihatkan kepada saya, ketika saya masih berpikir, adanya kekeliruan dalam argumen tentang Penyebab Pertama. Jika segala sesuatu harus memiliki suatu sebab, lalu tuhan juga harus memiliki suatu sebab. Jika mungkin ada sesuatu tanpa sebab, maka mungkin saja itu adalah dunia sebagaimana juga mungkin tuhan. Oleh karena itu, argumen tersebut tidak memiliki validitas apa pun.

Saya menemukan di antara banyak orang sekarang adanya suatu sikap tidak mengambil pilihan terhadap kebenaran yang saya kira sangat berbahaya. Ketika orang menyatakan pendapat, misalnya, untuk membela Kristen, mereka itu, seperti Thomas Aquinas, tidak mengemukakan alasan untuk menyatakan bahwa tuhan adalah ada dan bahwa Dia mengungkapkan kehendak-Nya dalam kitab suci.

Penulis tidak bermaksud untuk mengemukakan kritik Russel terhadap argumen adanya tuhan dalam teologi Aquinas. Kritik Russel relevan dikemukakan di sini karena kritik tersebut

memulai penciptaan/ tuhan (konklusi). Analogi tersebut adalah keliru karena bertolak dari premis, statemen, atau pengandaian yang justeru dipersoalkan kebenarannya berdasarkan akal pikiran, bukan atas dasar keyakinan teologis agama. Lihat lebih lanjut, misalnya: Patrick J. Hurley, A Concise Introduction to Logic (California: Wadsworth Publishing Company, 1985), h. 120-122. Pola pikir filosof dalam menyelesaikan rangkaian sebab-akibat tersebut dengan ad infinitum sebenarnya juga diterapkan oleh kalangan teolog Islam dengan kemustahilan adanya dawr dan tasalsul, misalnya, ketika menjelaskan sifat qidam Allah swt.

${ }^{3}$ Bertrand Russel, Why I am Not a Christian (an Other Essays on Religion and Related Subjects), ed. Paul Edward (New York: Simon \& Schuster, Inc., 1957), cet. Ke-41, h. 6-7.

${ }^{4}$ Bertrand Russel, Why I am Not a Christian, h. 196-197. 
juga merupakan kritik terhadap pendukung-pendukung argumen tersebut, termasuk kalangan filosof Islam, semisal Ibn Sînâ.

Menurut Russel, jika secara rasional diasumsikan bahwa rangkaian sebab-akibat tersebut, dengan prinsip ad infinitum, tidak mungkin berputar ulang dan mesti berhenti pada Penyebab Pertama yang kemudian di kalangan filosof yang bertuhan disebut dengan tuhan, maka bukankah secara rasional-jika kita sepakat dengan menggunakan spekulasi murni dan kebebasan rasio tanpa batas_-untuk lalu bertanya: apa atau siapa yang menjadi sebab bagi tuhan, jika diasumsikan bahwa di jagat raya ini segala sesuatu ada karena adanya sebab?

Kritik Russel tersebut, sebenarnya jika orang bertolak dari pertimbangan rasional sematamata untuk membuktikan adanya tuhan, pernah dikemukakan dengan bahasa yang lugas oleh seseorang yang baru diperkenalkan dengan Islam pada masa Rasulullah saw. "Jika langit, bumi, dan segala isinya diciptakan oleh Allah swt., lantas siapa yang menciptakan Allah swt sendiri?”, tanyanya. ${ }^{5}$ Dengan peristiwa tersebut, kita bisa menyimpulkan bahwa Islam memang mendorong manusia untuk menggunakan akalnya dalam batas-batasnya secara metodis dan bertanggung-jawab (lihat ilustrasi skema pada bagian akhir tulisan ini). Peristiwa itu juga menunjukkan bahwa kebebasan berpikir rasional harus dibatasi oleh kebenaran-kebenaran yang sudah diberikan oleh al-Qur'an, seperti tentang persoalan sangat penting itu, yaitu ketuhanan.

Di samping Bertrand Russel, Emmanuel Kant juga mengkritik validitas argumen rasional pembuktian adanya tuhan tersebut. Menurut Kant, argumen rasional yang ingin membuktikan adanya tuhan tersebut statusnya sama-sama kuat dengan argumen yang menyatakan sebaliknya (antinomi). Hal itu karena secara rasional, tidak alasan yang lebih kuat untuk menjadikan rangkaian sebab-akibat tersebut berhenti pada Penyebab Pertama. Bahwa tuhan adalah ada atau tidak ada adalah sama-sama tidak bisa dibuktikan secara rasional dalam konteks ini.

Dalam keadaan di mana argumen rasional seperti itu, kita dihadapkan pada pilihan: percaya atau tidak dengan adanya tuhan. Para filosof yang beragama, termasuk filosof Islam, dalam hal ini telah melakukan pilihan untuk percaya dengan adanya tuhan. Atau dengan ungkapan lain, yang mereka terapkan bukanlah pemikiran spekulatif murni yang mengasumsikan kebebasan akal tanpa batas, melainkan spekulasi akal yang masih memperhitungkan kebenaran kitab suci yang jelas menunjukkan adanya tuhan. Di kalangan filosof Islam, al-Qur'an adalah sumber kebenaran yang harus diterima, termasuk tentang adanya tuhan.

\section{Peran al-Qur'an dalam Perkembangan Filsafat Islam}

Akal dengan contoh di atas tampak begitu lemah untuk secara mandiri tanpa naungan wahyu untuk membuktikan adanya tuhan. Kenyataan ini menyebabkan kalangan filosof Islam menganggap akal teoritis (al-'aql an-nazhari) dalam konsep Aristoteles tidak harus diterapkan atas dasar kebebasan absolut, melainkan harus "diislamisasi” (islamized). Konsep seperti ditemukan, misalnya, pada konsep 'aql dalam filsafat Mulla Shadra ketika menafsirkan ayat-ayat al-Qur'an yang memuat kata 'aqldan bentuk turunannya, seperti ta' qilûn dan ya'qilûn (misalnya: Qs. al-Baqarah/ 2: 44 dan 164). Begitu juga, konsep 'aql seperti itu juga kita temukan dalam bagian 'aql dalam

${ }^{5}$ Lihat A. J. Wensinck, The Muslim Creed: Its Genesis and Historical Development (New Delhi: Oriental Books Reprint Corporation, 1979), h. 54. 
koleksi hadits Syî'ah oleh al-Kulaynî, Ushûl al-Kâfî. Upaya islamisasi konsep-konsep Yunani tersebut juga terlihat pada pengalihbahasaan kata nous (Yunani, bermakna: intelek) yang kemudian diberikan muatan makna Islam dalam konsep 'aql dalam filsafat Islam, seperti al- 'aql al-fa" âl pada karyakarya filosof Islam Peripatetik, seperti Ibn Sînâ yang menyejajarkan istilah ini dengan rûh alqudus (roh suci, sebutan untuk Jibrîl yang membawa wahyu), sebagaimana disebutkan dalam alQur'an. ${ }^{6}$

Al-Qur'an adalah sentral bagi perkembangan filsafat Islam. Yûsuf Mûsâ dalam al-Qứân wa al-Falsafah, ${ }^{7}$ bahkan, memandang al-Qur'an sebagai faktor utama, sesudah persentuhan kaum muslimin dengan karya-karya Yunani, yang menyebabkan perkembangan yang semarak dalam filsafat Islam. Kita bisa melihat peran al-Qur'an dalam perkembangan filsafat Islam dalam beberapa segi.

Pertama, istilah lain filsafat Islam, yaitu al-hikmah, diambil dari al-Qur'an (Qs. al-Baqarah/ 2: 269 dan Âli 'Imrân/3: 48) dan hadits, sebagaimana dikemukakan sebelumnya. Penyebutan al-hikmah untuk filsafat Islam untuk menunjukkan bahwa di samping bahwa kebenaran akal diakui perannya dalam Islam, juga bahwa penggunaan akal harus tetap merupakan basis penguat kebenaran-kebenaran yang disampaikan oleh wahyu. Ide bahwa filsafat dan agama tidak bertentangan, seperti dikemukakan oleh Ibn Rusyd dalam Fashl al-Maqâl fimâ Bayn al- $\underline{\text { Hikmah }}$ wa asy-Syariah min al-Ittishâl, memperjelas peran kitab suci dalam pencarian kebenaran melalui spekulasi akal.

Kedua, al-Qur'an mendorong manusia untuk menggunakan pemikiran akal dengan intensif dalam memahami agama dengan ungkapan seperti afalâ táqilûn, afalâ tataddabarûn, dan afalâ yatadabbarûn. Tidak diragukan lagi bahwa akal merupakan sarana penting untuk memahami Islam. Bahkan, al-Qur'an dalam menyampaikan ajararan-ajarannya, di samping, menggunakan metode khithâbî (retorik), yaitu menyampaikan pesan secara retorik tanpa disertai dengan argumen rasional di dalamnya, juga menggunakan metode burbânî (demonstratif), yaitu menggunakan alasan-alasan rasional yang dapat diterima oleh semua orang. Penggunaan metode burbânî terutama berkaitan dengan ajakan al-Qur'an kepada manusia untuk bertauhid.

Berikut dikemukakan contoh-contoh "logika" al-Qur'an:

1. Ketika menjelaskan tauhid, Qs. al-Anbiyâ‘ /21: 22 menunjukkan ketidaklogisan pengandaian banyaknya tuhan dalam ayat berikut:

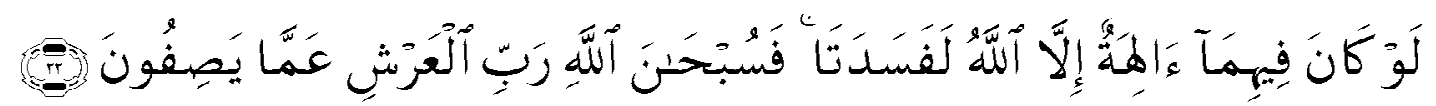

Sekiranya ada di langit dan di bumi tuhan-tuhan selain Allah, tentulah keduanya itu telah rusak. Maka Maha Suci Allab yang mempunyai 'arsy dari apa yang mereka sifatkan.

2. Ketika menjelaskan adanya kebangkitan, sebelum menyimpulkan suatu kesimpulan yang berisi keyakinan, al-Qur'an mengemukakan runut berpikir secara logis. Dengan memperhatikan secara seksama, kita akan memperoleh gambaran "logika" al-Qur'an seperti dalam rangkaian ayat-ayat berikut:

'Seyyed Hossein Nasr, “"'The Qur'an and Hadith", h. 28.

${ }^{7}$ Yûsuf Mûsâ, al-Qur'ân wa al-Falsafah, terjemah M. Thalib (Yogyakarta: Tiara Wacana, 1991), h. 159. 


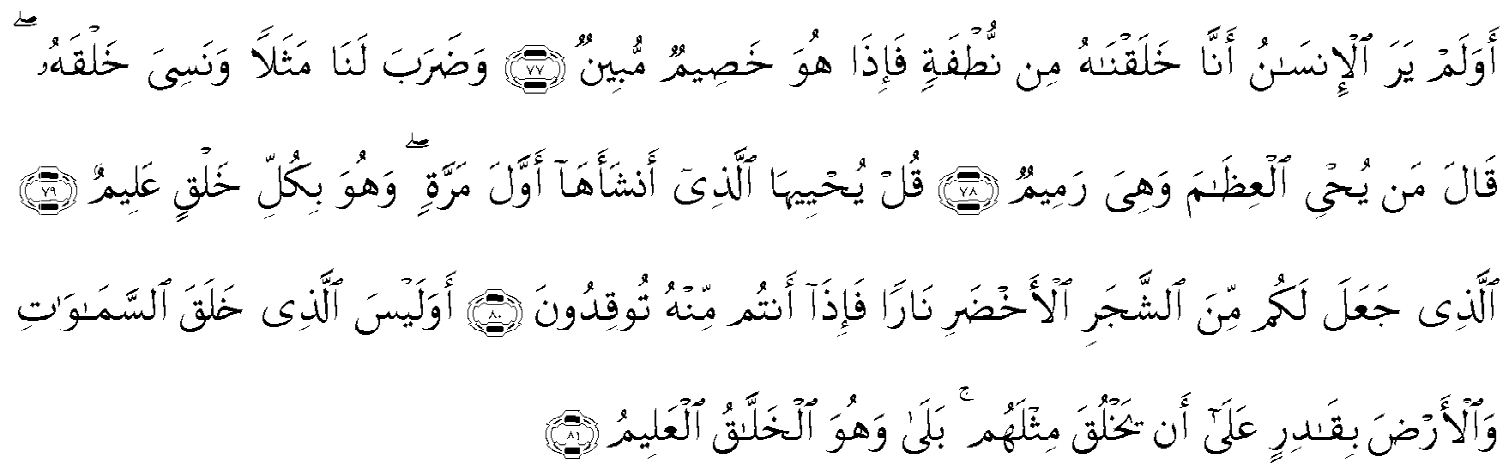

Dan apakah manusia tidak memperhatikan bahwa Kami telab menciptakanny a dari setitik air (mani), lalu tiba-tiba ia menjadi penantang yang nyata. [77] Dan dia membuat perumpamaan bagi Kami dan dia lupa tentang kejadiannya. I a bertanya: "Siapakah yang dapat menghidupkan tulang belulang yang telah hancur lulub?" [78] Katakanlah: "Ta akan dibidupkan oleh Tuban yang menciptakannya pertama kali. dan Dia Maha mengetahui tentang segala makbluk. [79] Yaitu Tuhan yang menjadikan untukmu api dari kayu yang hijau, lalu tiba-tiba kamu bisa menyalakan (api) dari kayu itu”. [80] Tidaklah Tuhan yang menciptakan langit dan bumi itu kuasa menciptakan yang serupa dengan itu? Tentu saja, Dia kuasa. Dialah yang Maha Pencipta lagi Maha Mengetahui.

Sebagaimana tampak pada kutipan ayat-ayat di atas, al-Qur'an tidak secara langsung menyampaikan suatu keyakinan tentang kebangkitan manusia, kecuali setelah dikemukakan runut berpikir logis. Pada ayat 79, untuk menyatakan bahwa "Allah swt Maha mengetahui tentang ciptaan-Nya" (wa buwa bikulli khalqin 'alîm), dikemukakan argumen rasional tentang kekuasaan Tuhan menciptakan manusia ketika awal kejadian yang pertama. Argumen ini diperkuat kembali pada ayat berikutnya tentang kekuasaan Tuhan untuk menciptakan panas api dari pohon hijau. Selanjutnya, pada ayat 81 untuk menyimpulkan bahwa "Allah swt adalah Maha Pencipta lagi Maha Mengetahui" (redaksi ayat secara teliti mengungkapkan dengan ungkapan yang berbeda dengan ungkapan sebelumnya, yaitu: wa huwa al-khallâq al-'alìm), al-Qur'an mengemukakan kemahakuasaan Tuhan untuk menciptakan langit dan bumi yang lebih besar daripada manusia. Dengan runut berpikir logis tentang kemampuan Tuhan untuk menciptakan manusia dari tiada ke ada, seperti pada kejadian awal, atau pada penciptaan panas api dari kayu basah (hijau), hingga kemampuan Tuhan untuk menciptakan langit dan bumi, al-Qur'an berargumen: bukankah lebih logis untuk menerima pernyataan bahwa Tuhan Maha Kuasa membangkitkan manusia yang telah menjadi tulang-belulang yang berserakan, sesuatu yang ada wujudnya sebelumnya? Karena itu hal itu lebih mudah-dalam skala logika manusia, meski dalam kekuasaan Tuhan semuanya adalah mudah, seperti dinyatakan dalam ayat berikutnya (83) untuk diciptakan atau dibangkitkan kembali. "Logika" al-Qur'an tersebut dikemukakan agar manusia menggunakan akalnya.

"Logika" al-Qur'an seperti ini juga bisa ditemukan pada ayat-ayat lain, seperti Qs. alHajj/22: 5-7 berikut:

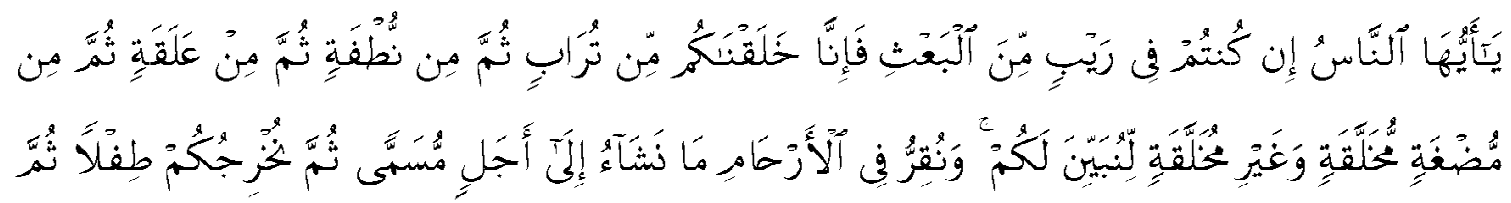




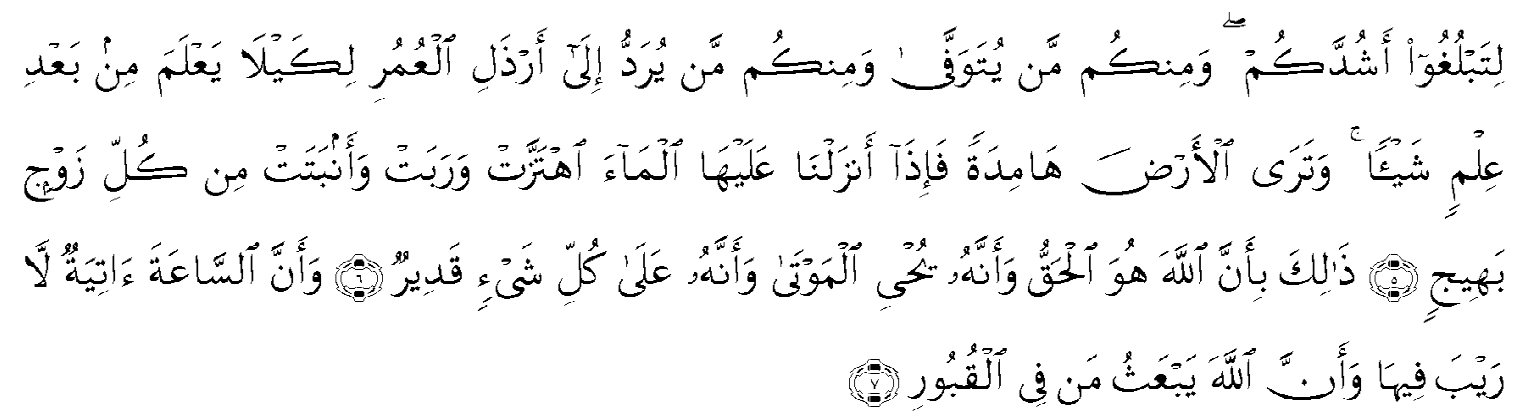

Hai manusia, jika kamu dalam keraguan tentang kebangkitan (dari kubur), sesunggubnya Kami telah menjadikan kamu dari tanah, kemudian dari setetes mani, dari segumpal darah, kemudian dari segumpal daging yang sempurna kejadiannya dan yang tidak sempurna agar kami jelaskan kepada kamu dan kami tetapkan dalam rahim sesuai apa yang Kami kehendaki sampai waktu yang sudah ditentukan. Kemudian, Kami keluarkan kamu sebagai bayi, kemudian (dengan berangsur-angsur) kamu sampailah kepada kedewasaan, dan di antara kamu ada yang diwafatkan dan (ada pula) di antara kamu yang dipanjangkan umurnya sampai pikun, supaya dia tidak mengetahui lagi sesuatupun tentang keadaan sebelumnya telah diketahuinya. Kamu libat bumi ini kering, kemudian apabila telah kami turunkan air di atasnya, biduplab bumi itu dan menjadi subur serta dapat menumbubkan berbagai macam tumbubtumbuhan yang indah [5]. Yang demikian itu, karena sesungguhnya Allah, dialah yang haq dan sesungguhnya Dialah yang menghidupkan segala yang mati dan sesunggubnya Allah Maha Kuasa atas segala sesuatu [6]. Sesunggubnya hari kiamat itu pastilah datang, tak ada keraguan padanya dan bahwasanya Allah akan membangkitkan semua orang di dalam kubur [7].

"Analogi" dengan model yang sama juga ditemukan pada Qs. Fushshilat/41: 39 berikut:

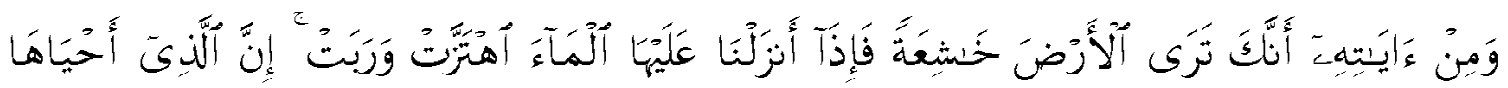

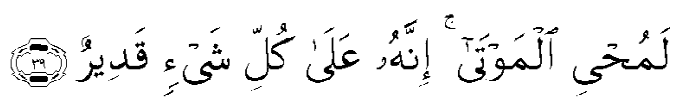

Dan di antara tanda-tanda-Nya adalab bahwa kamu libat bumi yang kering dan gersang. Apabila Kami turunkan air di atasnya, niscaya ia bergerak dan subur. Sesunggubnya Tuban yang menghidupkannya pastilah dapat menghidupkan yang mati. Sesungguhnya dia Maha Kuasa atas segala sesuatu.

Yûsuf Mûsâ mengkategorikan analogi seperti dalam ayat-ayat al-Qur'an di atas "analogi dari persoalan yang kongkret (syâhid) untuk sampai ke kesimpulan tentang tuhan sebagai yang abstrak (ghâib)" (قياس الغائب على الشاهد atau), atau lebih khusus, qiyâs al-awlâ, yaitu bentuk analogi yang bertolak dari persoalan yang lebih sulit dicerna oleh akal pikiran ke analogi persoalan yang lebih mudah dimengerti dan lebih rasional untuk diterima.

Ketiga, al-Qur'an mengandung ayat-ayat mubkeam dan mutasyâbih. Menurut Fakhr ad-Dîn ar-Râzî, hikmah keberadaan dua macam ayat tersebut, antara lain, untuk mendorong perkembangan pemikiran dan aliran dalam Islam serta tidak ada taqlìd, karena setiap ajaran Islam harus dituntut pengetahuan yang disertai argumennya. Fakhr ad-Dîn ar-Râzî mengatakan (terjemahnya): 
“Kalau semua ayat al-Qur'an itu mubkeam, berarti hanya sejalan dengan satu aliran pemikiran dan berarti statemennya yang mengandung satu pengertian itu membatalkan adanya aliran pemikiran lainnya. Hal semacam ini akan membuat pemikir-pemikir dari berbagai aliran pemikiran menjauhkan diri dari al-Qur'an dan dari teori yang ada di dalamnya. Sesungguhnya, karena suatu hal, ayat mutasyâbih memaksa orang untuk memikirkan ayat tersebut dengan memerlukan bantuan argumentasi rasional dan dengan cara demikian ia terlepas dari taqlìd'. 8

Di samping alasan tersebut, menurut Fakhr ad-Dîn ar-Râzî, alasan terkuat adalah karena al-Qur'an adalah kitab suci yang ditujukan kepada semua lapisan manusia dengan berbagai level pemahaman yang berbeda. Pola pemikiran kalangan awam adalah kemampuan memahami lahiriah teks. Oleh karena itu, kepada mereka keimanan ditanamkan melalui ayat-ayat yang mubkam. Sedangkan, kelompok ahli memiliki kemampuan untuk menafsirkan secara simbolik atau metapor (majâzîl) makna-makna terdalam di balik teks ayat-ayat yang mutasyâbih.

Di samping memuat mubkam dan mutasyâbih, al-Qur'an berdasarkan sebuah hadits memiliki "makna lahiriah" (z̧hâhir) dan "makna batin" (bâthin), atau dengan istilah lain, hadd dan mathla', karena sifat al-Qur'an yang multi-aspek (wujûh, multiface) yang disebabkan oleh beberapa faktor, baik faktor-faktor dari dalam teks, seperti problem kebahasaan, maupun faktor-faktor dari luar teks, seperti kondisi sosio-historis, ${ }^{9}$ selama bertolak dari kaedah, prinsip, atau metode penafsiran yang benar dan bertanggung-jawab, adalah sesuatu yang diijinkan oleh tuhan, karena perbedaan aliran dan pemahaman tafsir tersebut merupakan implikasi dari dorongan al-Qur'an untuk menggunakan akal. 'Alî bin Abî Thâlib pernah menyatakan sebagai berikut:

لاتحاصمهم بالقرآن, فإن القرآن حمال ذو و جوه, تقول و يقولون, و لكن حاججهم بالسنة, فإذهم لن 10

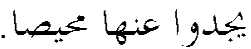

Janganlah kamu membantah mereka (Khawârij) dengan menggunakan al-Qur'an, karena al-Qur'an memiliki kemungkinan dipahami dengan beberapa makna, memiliki banyak aspek. Kamu mengatakan dari satu sisi, tapi mereka juga bisa mengatakan dari sisi lain. Tapi, debatlah mereka dengan menggunakan sunnah, karena dengan cara itu mereka tidak akan menemukan jalan untuk menghindar.

Dengan sifat al-Qur'an yang multi-face tersebut, selama bertolak dari pemahaman yang ditopang oleh prinsip-prinsip penafsiran yang valid, pemahaman-pemahaman yang beragam diakui keberadaannya, baik dari kalangan teolog (mutakallimûn), ahli hukum Islam (fuqahấ),

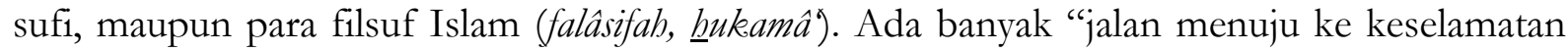
atau kedamaian” (subul as-salâm, طرق النجاة و السلامة و مناهج الاستقامة (11), termasuk “jalan” (sabîl) para filsuf. Meski demikian mengakui adanya pluralitas pemahaman, al-Qur'an memberikan rambu-rambu untuk menuju kebenaran yang bisa dirangkum dalam skema berikut yang bertolak

${ }^{8}$ Yûsuf Mûsâ, al-Qur'ân wa al-Falsafah, h. 28.

${ }^{9}$ Lihat Sa'ûd 'Abdullâh al-Fanîsân, Ikbtilâf al-Mufassirin: Asbâbuh wa Âtsârub (Riyadh: Markaz ad-Dirâsât wa al-I’lâm, 1997/ 1418), h. 8-9.

${ }^{10}$ Asy-Sharîf ar-Râdhî, Nahj al-Balâghah (Beirut: Mu'assasat al-A’lamî li al-Mathbû'ât, 1993), juz 3, h. 622-623.

${ }^{11}$ Abû al-Fidâ‘ Ismâ’îl Ibn Katsîr, Tafsîr Ibn Katsîr (Beirut: Dâr al-Fikr, 1986), juz 1, h. 25. 
dari Qs. al-Mâ'idah: 16 dan perbedaan antara kata "subul' (bentuk jamak sabîl) dan "shirât" pada ungkapan "shirâth mustaqîm" :

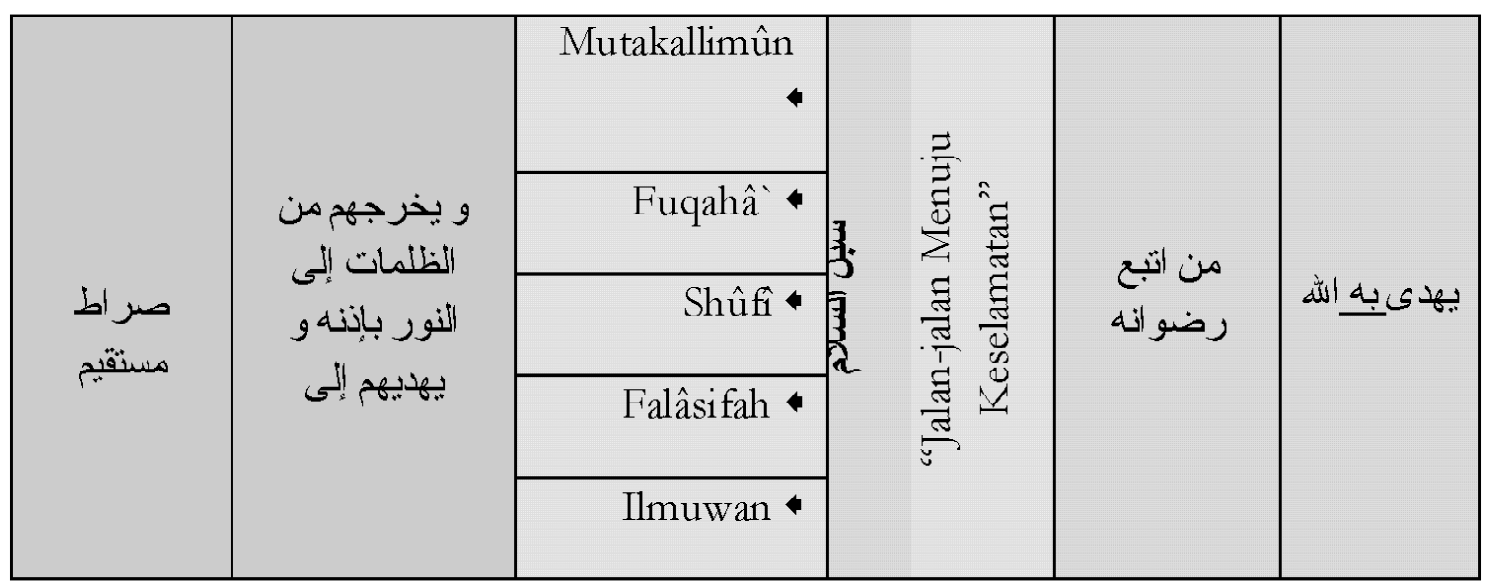

Goal

Error

Process

Motivation Guidance

\section{Elimination}

(Eliminasi

(Kebenar- kesalahan

an)

$$
\begin{aligned}
& \text { dalam berpikir } \\
& \text { supaya ada } \\
& \text { kcsimpulan } \\
& \text { yang dituju) }
\end{aligned}
$$
(Pluralitas pemahaman dan
pendekatan)
(Pencarian (al-Qur'an
Kebenaran; dan ikhlash) Sunnah plus nalar)

(Terjemah: Dengan Kitab Itulah Allah menunjuki orang-orang yang mengikuti keredhaan-Nya ke jalan-jalan keselamatan, dan mengeluarkan mereka dari kegelapankegelapan kepada cahaya dengan seizin-Nya, dan menunjuki mereka ke “jalan yang lurus”).

Keempat, al-Qur'an memuat diskusi tentang isu-isu yang kemudian memberikan inspirasi bagi diskusi yang mendalam dalam filsafat Islam. Berikut dikemukakan beberapa contoh:

1. Diskusi tentang dzât dan sifat Allah swt. Dalam Qs. al-Baqarah/2: 20 dinyatakan:

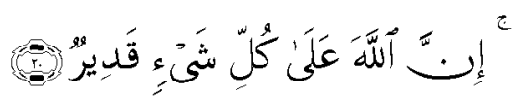

Sesunggubnya Allah Maha Kuasa atas segala sesuatu.

\footnotetext{
${ }^{12}$ Bandingkan dengan uraian dalam M. Quraish Shihab, Tafsir al-Mishbah: Pesan, Kesan, dan Keserasian al-Qur'an (Jakarta: Lentera Hati, 2000), Volume 1, h. 53.
} 
Dalam Qs. al-Baqarah/2: 256 berikut dinyatakan:

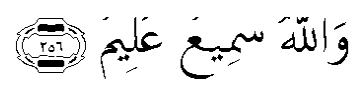

\section{Dan Allah Maha Mendengar lagi Maha Mengetahui.}

Berdasarkan dua ayat tersebut di atas, diyakini bahwa Allah swt memiliki kuasa (qudrab), kemampuan mendengar ( $(\mathrm{sam}$ ), dan kemampuan mengetahui ('ilm). Kaum muslimin generasi awal Islam menerima pengertian adanya sifat-sifat Allah swt tanpa mempersolkan bagaimana "cara bekerjanya" ketiga sifat tersebut. Sejak terjadinya polarisasi umat Islam kepada sekte-sekte, respon terhadap persoalan ini menjadi beragam, antara lain, karena tingkat rasionalitas pemikiran yang berbeda. Kalangan Mu'tazilah meyakini bahwa Allah swt adalah Maha Kuasa, Maha Mendengar, dan Maha Mengetahui dengan dzâtnya. Sedangkan, Asy'ariyah meyakini semua itu beroperasi dengan sifat-Nya, bukan dzâtnya seperti diklaim oleh Mu'tazilah.

Harry Austryn Wolfson menyimpulkan bahwa persoalan tentang sifat tuhan sebagaimana didiskusikan secara rumit oleh umat Islam belakangan berabad-abad setelah masa Rasulullah saw adalah sesuatu yang baru dalam kalâm. Problem awalnya adalah problem semantik tentang bagaimana al-Qur'an mendeskripsikan tuhan untuk membedakan-Nya dari makhluk-Nya. ${ }^{13}$ Formulasi tentang sifat tuhan yang tercatat pernah dikemukakan oleh Sulaymân ibn Jarîr az-Zaydî (785) dari Syî'ah. Dalam Maqâlât al-Islâmiyîn karya al-Asy'arî dikutip formulasi az-Zyadî tersebut: "Pengetahuan (sifat ilmu) tuhan bukanlah tuhan sendiri". Formulasi ini kemudian digunakan oleh Hisyâm ibn $\underline{\text { Hakam }}$ (w. 814) yang juga seorang penganut Syî’ah. Ibn Kullâb (w. 854), seorang Sunni, memformulasikan: "Tuhan secara kekal (qadîm) berkehendak melalui kehendak-Nya yang tidak bisa dikatakan sebagai tuhan sendiri, tapi tidak juga sesuatu yang lain dari tuhan". ${ }^{14}$ Seabad kemudian, formulasi Ibn Kullâb diadopsi oleh Abû Hâsyim (w. 933). Ia mengubah istilah "sifat" dari Ibn Kullâb menjadi "keadaan" (hâl, mode). "Bukan tuhan” dalam formulasi Ibn Kullâb diartikan dengan penolakan pandangan Mu'tazilah bahwa istilah yang dilekatkan pada tuhan semata-mata nama yang menunjukkan esensi tuhan, dan "bukan juga sesuatu yang lain dari tuhan" adalah penolakan pandangan orang yang menetapkan adanya sifat tuhan bahwa istilah yang dilekatkan pada tuhan menunjukkan keberadaan sifat nyata pada tuhan yang sebenarnya harus dibedakan dari dzât-Nya. Bersamaan dengan Abû Hâsyim, al-Asy'arî juga mengadopsi formulasi Ibn Kullâb. Tentang pengetahuan ( $\mathrm{ilm}$ ) tuhan, misalnya, al-Asy'arî mengatakan bahwa "seseorang seharusnya tidak mengatakannya sebagai sesuatu selain tuhan". ${ }^{15}$ Setelah al-Asy'arî, persoalan ini tetap saja menggelayuti diskusi kalâm di tangan tokoh-tokoh, seperti al-Bâqillânî. Para mutakallimûn dalam menjelaskan persoalan tersebut sering menggunakan frase linafsibi atau binafsibi (karena diri-Nya sendiri).

\footnotetext{
${ }^{13}$ Harry Austryn Wolfson, The Philosophy of the Kalam (Cambridge: Harvard University Press, 1976), h. 206.

${ }^{14}$ Harry Austryn Wolfson, The Philosophy of the Kalam, h. 207-208.

${ }^{15}$ Harry Austryn Wolfson, The Philosophy of the Kalam, h. 211-212.
} 
Persoalan dzât dan sifat dalam al-Qur'an, akhirnya, didiskusikan secara filosofis sebagai persoalan filsafat tentang substansi dan aksidensi. Dalam penggunaan istilah-istilah tersebut, diskusi tentang ajaran al-Qur'an ini merambah diskusi filsafat, khususnya filsafat Aristoteles (382-322 SM).

Dalam diskusi tentang dzât dan sifat tuhan sebagaimana berkembang dalam sejarah seperti itu, memang kita tidak bisa menyangkal bahwa akar sejarah filsafat Islam, antara lain, berasal dari filsafat Yunani, khususnya dalam diskusi ini pandangan Aristoteles tentang sepuluh kategori (al-maqûlât al-'asyrah), terutama tentang substansi dan aksiden. Meskipun demikian, diskusi tersebut tidak akan mendapatkan spirit yang kuat jika tidak bersentuhan langsung dengan ajaran al-Qur'an tentang tuhan dalam konteks ini. Peran sentral al-Qur'an inilah yang menyebabkan Ira M. Lapidus berkesimpulan bahwa motivasi penerjemahan karya-karya Yunani ke bahasa Arab, antara lain, didorong oleh spirit keagamaan tentang keinginan menjelaskan fondasi rasional bagi Islam. Ia mengatakan: "Philosophy, however, was not a neutral form of analysis, but itself a kind of religion" (Akan tetapi, filsafat bukanlah suatu bentuk analisis yang netral, melainkan suatu bentuk agama juga). ${ }^{16}$

Para filosof Islam telah berjasa mempertemukan akar sejarah dan dasar tekstual filsafat Islam. Para teolog Mu'tazilah generasi awal, seperti Abû al-Hudzayl al-'Allâf dan anNazhzhâm, yang bersentuhan langsung dengan filsafat Yunani adalah "filosof Islam generasi awal" (falâsifat al-Islâm al-asbaqûn), menurut Nader. Mereka mengadopsi, mengadaftasi, dan memodifikasi metode filsafat untuk digunakan dalam kalâm serta mendiskusikan isuisu ketuhanan dengan perspektif filsafat. Kreativitas Mu'tazilah seperti itulah yang kemudian dalam karya-karya heresiografi Asy'ariyah, seperti al-Milal wa an-Nihbal asy-Syahrastânî dan al-Farq bayn al-Firaq al-Baghdâdî, dikatakan "mengada-adakan sesuatu yang sebelumnya tidak ada" (bid'ah) dengan mempertanyakan suatu ajaran yang sebelumnya tidak dipertanyakan. Sejarah kemunculan dan perkembangan ilmu kalâm, sebagaimana dijelaskan oleh Ibn Khladûn dan asy-Syahrastânî, menjelaskan bagaimana proses terjadinya internalisasi filsafat ke kalâm untuk menyikapi persoalan-persoalan agama yang semula bergerak dalam orientasi penanganan sederhana fiqh. Karena tidak hanya filsafat Islam yang berupaya memahami ajaran-ajaran al-Qur'an, seperti tampak dalam diskusi tentang dzât dan sifat tuhan di atas, dengan skema filsafat, melainkan juga kalâm ikut ambil bagian dalam diskusi tentang hal itu. Justreu karena peran yang dimainkannya, kalâm filosofis menjadi bagian kreativitas yang cemerlang dalam filsafat Islam.

2. Tentang kosmologi, misalnya, dalam Qs. an-Nûr/24: 35 berikut:

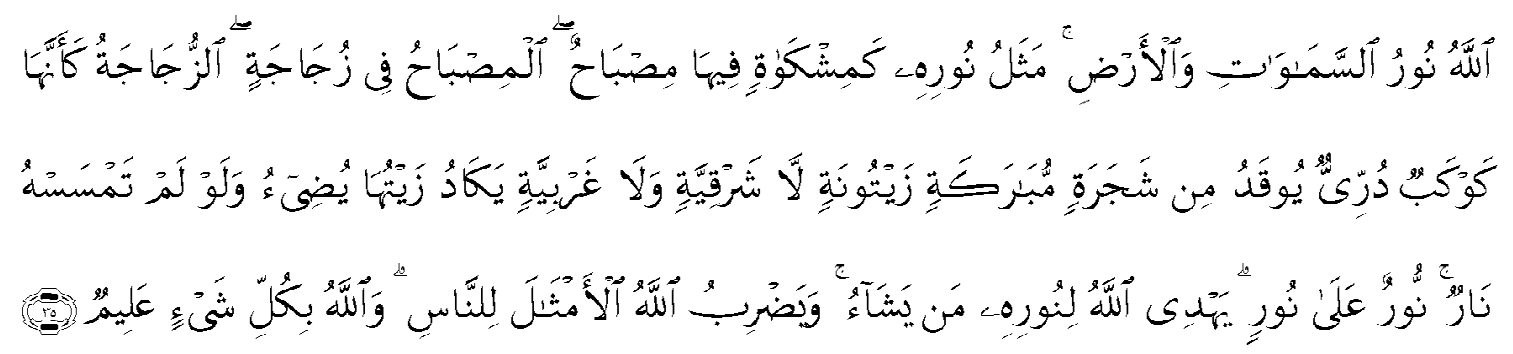

\footnotetext{
${ }^{16}$ Ira M. Lapidus, A History of Islamic Societies (Cambridge: Cambridge University Press, 1999), h. 94.
} 


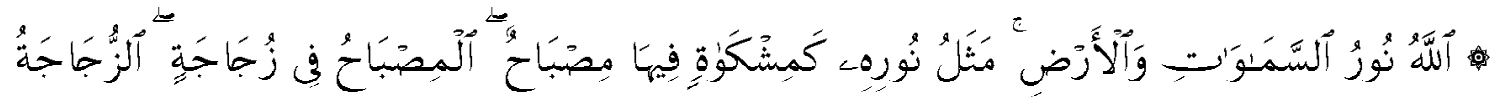

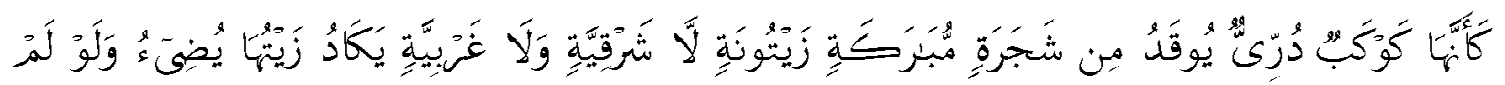

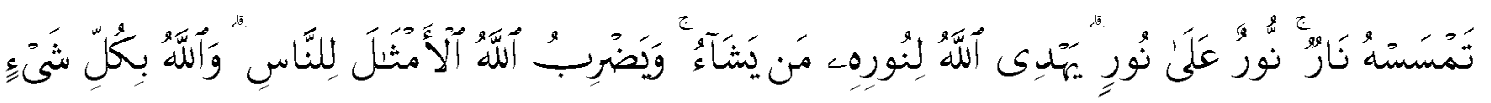

Allah adalah (Pemberi) cahaya langit dan bumi. Perumpamaan cahaya Allah adalah seperti sebuah lubang yang tak tembus yang di dalamnya ada pelita besar. Pelita itu berada di dalam kaca, (dan) kaca itu seakan-akan seperti bintang (yang bercahaya) seperti mutiara, yang dinyalakan dengan minyak dari pohon yang diberkahi, (yaitu) pohon zaitun yang tumbuh tidak di sebelah timur (sesuatu) dan tidak pula di sebelah barat yang minyaknya (saja) hampir-hampir bisa menerangi, walaupun tidak disentuh api. Cabaya di atas cabaya (berlapis-lapis). Allah membimbing kepada cabaya-Nya siapa saja yang Dia kehendaki, dan Allah membuat perumpamaan-perumpamaan bagi manusia, dan Allah Maha mengetahui segala sesuatu.

Sebagaimana diketahui, ayat-ayat al-Qur'an memuat dua lapisan makna, yaitu "makna luar atau makna lahiriah" (zhâhirir) dan "makna batin" (bâthin). Makna yang terakhir ini yang kemudian disejajarkan dengan haqîqah yang ingin digali oleh kalangan para filosof Islam dan sufi. Memang, tidak semua tokoh Islam sepakat dengan adanya majâz dalam al-Qur'an, seperti kritik Ibn Taymiah dan Ibn Qayim al-Jawziyah. Namun, sebagaimana tampak dalam ayat tersebut melalui ungkapan "dan Allah membuat perumpamaan-perumpamaan bagi manusia" (wa yadhrib Allâh al-amtsâl li an-nâs), ayat tersebut sangat berpotensi untuk dita wil secara metapor. Tidak hanya kalangan sufi, seperti al-Ghazâlî dalam Misykât al-Anwâr, melainkan juga kalangan filosof Islam mengemukakan pemikiran filsafatnya melalui ta 'mîl terhadap ayat tersebut. Berikut dikemukakan ta 'wîl ayat tersebut menurut Ikhwân ash-Shafầ sebagaimana dikutip oleh al-Jâbirî:

$$
\begin{aligned}
& \text { الله نور السموات و الأرض : يعنى العقل الكلي. } \\
& \text { بنور العقل الكلي كما تضيئ المشكاة بنور المصباح المشرق بنور الله. فيها مصباح, المصباح فن زجاجة, } \\
& \text { الزجاجة = هي الصورة الأولى (=الهيولى الأولى) الشفاقة المضيئة مما سرى فيها من فيض النفس عليها } \\
& \text { لفيض العقل الكلي على النفس الكلية كأها كو كب دري, هو الصورة المخردة المكو كبة بالأنواع الذاتية } \\
& \text { يوقد من شجرة مبركة زيتونة لا شرقية و, لا غربية :تكاد النفس الكلية تعطى الحلياة و الحركة لحميع }
\end{aligned}
$$

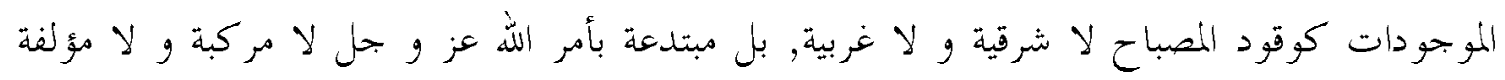

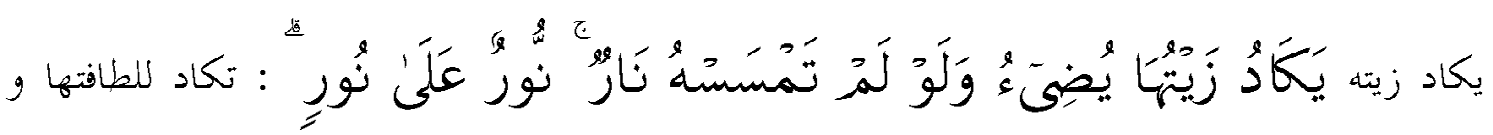

${ }^{17}$ Muhammad 'Âbid al-Jâbirî, Bun-yat al-'Aql al-'Arabî: Dirâsah Tablîliyah Naqdìyah li Nužbum al-Ma'rifah fî ats-Tsaqâfat al-Arabiyah (Beirut: al-Markaz ats-Tsaqâfî al-'Arabî, 1993), h. 283. 


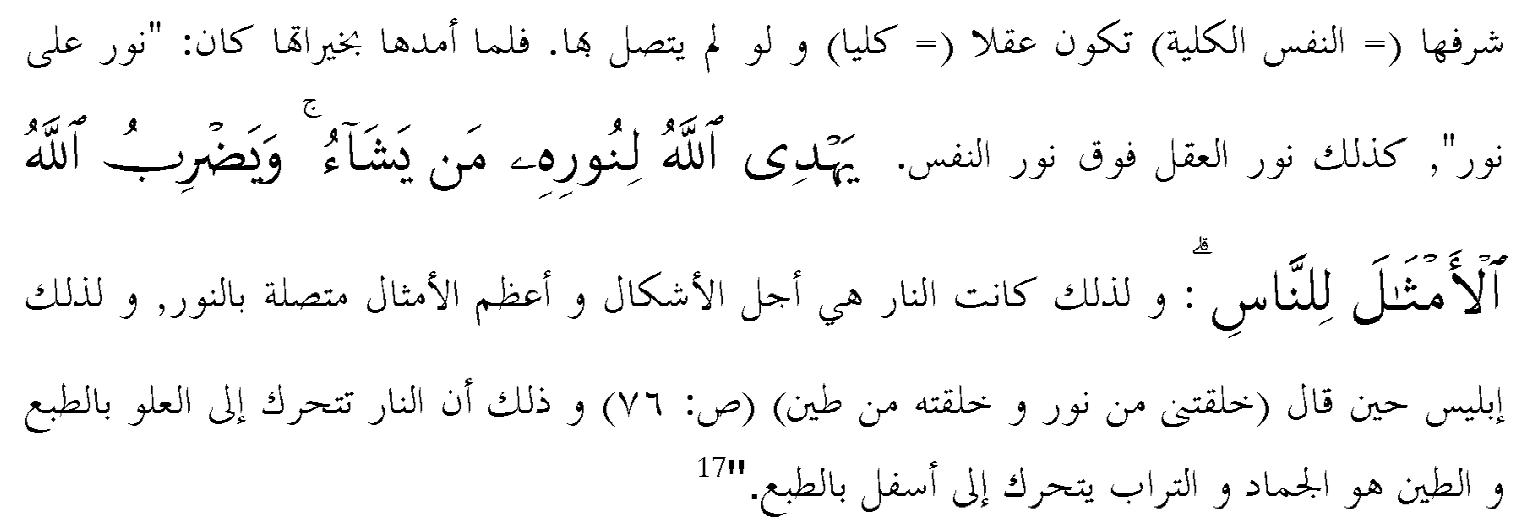

"Allah adalah cahaya langit dan bumi. Perumpamaan cahaya-Nya" maksudnya adalah akal universal, "seperti sebuah lubang yang tak tembus" maksudnya adalah jiwa universal yang muncul dari akal universal yang mampu menerangi dengan cahaya akal universal sebagaimana lubang yang tak tembus tersebut menerangi dengan cabaya lampu yang bersinar dengan cahaya Allab. "Di dalamnya ada pelita besar, dan pelita besar tersebut berada dalam kaca, sedangkan kaca tersebut adalah bentuk awal (alhayûlâ al-ûlâ) yang memberikan kasih sayang dan sinar karena adanya limpahan jiwa terhadapnya melalui limpahan akal universal terbadap jiwa universal. "Seakan-akan bintang (yang bercahaya) seperti mutiara", yaitu bentuk murni yang menyerupai bintang dengan berbagai sifat personalnya. "Yang dinyalakan dengan minyak dari pohon yang diberkabi, (yaitu) pohon zaytun yang tumbub tidak sebelah timur dan tidak pula di sebelah barat". Hampir saja jiwa universal tersebut mampu memberikan kebidupan dan gerak kepada semua yang ada seperti nyala pelita tersebut, tidak di timur maupun di barat, melainkan diciptakan dengan perintah Allab 'azza wa jalla, tidak berstruktur atau tersusun. "Minyaknya (zaytun) bampir saja mampu menerangi, meskipun tidak disentub oleh api, laksana cahaya di atas cahaya". Begitu juga, cahaya akal berada di atas cahaya jiwa. Allah membimbing kepada cahaya-Nya siapa yang Dia kehendaki, dan Allah membuat perumpamaan-perumpamaan bagi manusia. Oleh karena itu, api adalah bentuk yang paling mulia dan perumpamaan yang paling agung yang berbubungan dengan cahaya. Oleh karena itu, Iblis diuji ketika ia mengatakan: "Engkau ciptakan aku dari api, dan Engkau ciptakan dia (Adam) dari tanab” (Qs. Shâd: 76). Hal itu karena api dari segi sifatnya dapat bergerake ke tempat yang tinggi. Sedangkan, tanah adalah benda padat, dan tanah dari segi sifatnya bergerake ke tempat yang lebih rendah.

Sebagaimana tampak dalam kutipan di atas, ayat al-Qur'an dijadikan sebagai sumber inspirasi berfilsafat dengan melakukan ta'wîl dengan memalingkan nmakna-makna lahiriahnya ke gambaran-gambaran metafisis yang berkaitan dengan tuhan yang transenden, akal universal, jiwa universal, dan sebagainya. ${ }^{18}$ Dengan demikian, sebagaimana kalangan sufi, seperti yang dilakukan oleh al-Qusyairî, kalangan filosof Islam menerapkan ta'wîl terhadap ayat-ayat alQur'an untuk sampai ke pemikiran-pemikiran filsafat yang dikembangkannya. Dengan bersumber dari al-Qur'an sebagai inspirasinya, pantas dikatakan bahwa "filsafat Islam adalah filsafat prophetik, karena pada esensi filsafat Islam adalah hermeneutika filosofis untuk memahami teks kitab suci”. Seyyed Hossein Nasr mengatakan sebagai berikut:

\footnotetext{
${ }^{18}$ Muhammad 'Âbid al-Jâbirî, Bun-yat al-'A ql al-'Arabî, h. 283.
} 
A deeper study of Islamic philosophy over its twelve-hundred-year history will reveal the role of the Qur'an and hadith in the formulation, exposition and problematics of this major philosophical tradition. In the same way that all of the Islamic philosophers from al-Kindî onwards knew the Qur'an and hadith and lived with them, Islamic philosophy has manifested over the centuries its inner link with the revealed sources of Islam, a link which has become even more manifest as the centuries have unfolded, for Islamic philosophy is essentially a philosophical hermeneutics of the Sacred Text while making use of the rich philosophical heritage of antiquity. ${ }^{19}$

Suatu studi yang lebih mendalam tentang filsafat Islam dalam perjalanan sejarahnya selama dua belas abad akan bisa menunjukkan peran al-Qur'an dan hadîts, baik dalam memformulasikan, menjelaskan, maupun dalam pengembangan persoalan-persoalan yang muncul dalam tradisi filsafat utama ini. Dengan cara yang sama, di mana semua filsuf Islam sejak al-Kindî mengenal al-Qur'an dan hadîts serta hidup dengan kedua sumber tersebut, filsafat Islam selama berabad-abad menunjukkan keterkaitannya yang erat dengan sumber-sumber Islam yang diwahyukan, sebuah keterkaitan yang memiliki banyak bentuk seiring dengan perjalanannya beberapa abad, karena filsafat Islam pada dasarnya adalah sebuah hermeneutika filosofis tentang teks suci ketimbang menggunakan peninggalan kaya filsafat kuno.

Hubungan antara al-Qur'an dan hadits di satu sisi dengan filsafat Islam di sisi lain bisa dipahami dari sejarah filsafat Islam. Kaum muslimin mengidentifikasi Hermes yang juga dikenal di Barat melalui sumber Islam dengan Nabi Idrîs atau Nûh, rasul yang disebut dalam al-Qur'an dan hadits. Para filosof Islam menganggap Nabi Idrîs sebagai sumber filsafat dan menyebutnya sebagai abl al-hukamâ' (Bapak para filosof). Seperti halnya Plato, filosof Yunani yang terakhir, dan filosof Renaissance di Eropa, filosof Islam juga menganggap kenabian sebagai sumber filsafat. Perkataan Arab yang terkenal mengatakan: "Filsafat Islam bersumber dari sumber kenabian" (yanba' al-bikmah min misykât an-nubunwah) yang menggaung dalam sejarah Islam menunjukkan adanya hubungan antara filsafat dan kenabian. ${ }^{20}$

\section{Penutup}

Berdasarkan uraian yang telah dikemukakan, filsafat Islam, di samping berakar secara historis, juga memiliki hubungan dengan sumber-sumber tekstual, baik al-Qur'an maupun hadits. Upaya kompromisasi antara sumber historis dan sumber tekstual yang dilakukan oleh para filosof Islam sangat tampak dalam contoh-contoh di atas. Fakta sejarah ketika penerjemahan karya Yunani ke bahasa Arab yang, antara lain, didorong oleh motivasi keagamaan, seperti kesimpulan Ira M. Lapidus di atas, memperkuat bahwa filsafat tidak bisa dipisahkan dari sumber kenabian.

\footnotetext{
${ }^{19}$ Seyyed Hossein Nasr, “'”The Qur'an and Hadith”, h. 37.

${ }^{20}$ Seyyed Hossein Nasr, "'The Qur'an and Hadith", h. 30.
} 


\section{DAFTAR PUSTAKA}

Al-Fanîsân, Su'ûd 'Abdullâh, (1997M/1418H). Ikhtilâf al-Mufassirîn: Asbâbuh wa Âtsâruh. Riyadh: Markaz ad-Dirâsât wa al-I'lâm.

Hurley, Patrick J, (1985). A Concise Introduction to Logic. California: Wadsworth Publishing Company.

Al-Jâbirî, Muhammad 'Âbid, (1993). Bun-yat al-'Aql al-'Arabî: Dirâsah Tablîliyah Naqdiyah li Nu乏hum al-Ma'rifah fî ats-Tsaqâfat al-'Arabiyah (Beirut: al-Markaz ats-Tsaqâfî al-'Arabî. Lapidus, Ira M, (1999). A History of Islamic Societies. Cambridge: Cambridge University Press. Mûsâ,Yûsuf, (1991). al-Qur'ân wa al-Falsafah, terjemah M. Thalib. Yogyakarta: Tiara Wacana.

Russel, Bertrand, (1957). Why I am Not a Christian (an Other Essays on Religion and Related Subjects), ed. Paul Edward. New York: Simon \& Schuster, Inc.

Wensinck, A. J, (1979). The Muslim Creed: Its Genesis and Historical Development. New Delhi: Oriental Books Reprint Corporation.

Wolfson, Harry Austryn, (1976). The Philosophy of the Kalam (Cambridge: Harvard University Press. 